\title{
TOMANDO POSSE DA HISTÓRIA: O LEGADO DE RESISTÊNCIA DA CACIQUE KAWANY LOURDES TUPINAMBÁ
}

\author{
Cacique Kawany Lourdes Tupinambá (MInA - caciquelurdes@ gmail.com) \\ Daniella Santos Alves (PPGAS/UFSCar - danielasantos.alves@ hotmail.com) \\ Gabriela Gonçalves Junqueira (PPGAS/UFG - gabbi_gj@ hotmail.com)
}

\begin{abstract}
RESUMO: O PRESENTE ARTIGO É RESULTADO DE UMA EXPERIÊNCIA ETNOGRÁFICA E REFLEXÕES A PARTIR DAS DISCUSSÕES PÓS-COLONIAIS E DECOLONIAIS. TENDO COMO BASE ESSE DIÁLOGO, CONSTRUÍMOS TAL PRODUÇÃO TEXTUAL EM CONJUNTO COM CACIQUE KAWANY LOURDES TUPINAMBA, LIDERANÇA DO MOVIMENTO DOS INDÍGENAS NÃO ALDEADOS DO TRIÂNGULO MINEIRO E ALTO PARANAÍBA - MINA, SITUADO NA CIDADE DE UBERLÂNDIA - MG. A PARTIR DESSA PARCERIA FOI PENSADA A ESTRUTURA DO ARTIGO. OPTAMOS POR REVISITAR A HISTÓRIA DO CONTATO, O PROCESSO DE MARGINALIZAÇÃO E EMUDECIMENTO DO PROTAGONISMO INDÍGENA, A PARTIR DA HISTÓRIA DE VIDA, MEMÓRIA E O LEGADO DE RESISTÊNCIA DA CACIQUE TUPINAMBÁ. NOSSO OBJETIVO FOI, PORTANTO, O DE CRIAR ESPAÇOS INSTITUCIONAIS PARA QUE AS VOZES SUBALTERNAS SEJAM OUVIDAS DE FORMA EFETIVA. ALÉM DISSO, O INTUITO DE REGISTRAR OUTRAS VOZES, DIVULGAR OUTRAS HISTÓRIAS, PUBLICIZAR OS ANSEIOS E DESEJOS DOS INDÍGENAS INTEGRANTES DO MOVIMENTO POR INTERMÉDIO DA BIOGRAFIA DA CACIQUE KAWANY LOURDES TUPINAMBÁ CAMINHA EM DIREÇÃO DAS RECENTES DISCUSSÕES DE UMA ANTROPOLOGIA POR DEMANDA.
\end{abstract}

PALAVRAS CHAVES: HISTÓRIA INDÍGENA; ANTROPOLOGIA POR DEMANDA; MEMÓRIA

\section{TAKING OVER HISTORY: THE LEGACY OF CACIQUE KAWANY LOURDES TUPINAMBA RESISTANCE}

\begin{abstract}
THE PRESENT ARTICLE IS THE RESULT OF AN ETHNOGRAPHIC EXPERIENCE AND REFLECTIONS BASED ON DECOLONIALS AND POST-COLONIALS DISCUSSIONS. BUILT ON THOSE DIALOGUES, WAS CRAFT A TEXTUAL PRODUCTION JOINTLY WITH CACIQUE KAWANY LOURDES TUPINAMBA, THE LEARDERSHIP OF THE MOVIMENTO DOS INDÍGENAS NÃO ALDEADOS DO TRIÂNGULO MINEIRO E ALTO PARANAÍBA (MINA) (NON-VILLAGERS INDIGENOUS PEOPLE'S MOVEMENT OF THE TRIÂNGULO MINEIRO E ALTO PARANAÍBA, LOCATED IN UBERLÂNDA -MG. THE ARTICLE IS BASED ON THIS PARTNERSHIP. WE OPTED TO REVIEW THE HISTORY OF CONTACT, THE MARGINALIZATION PROCESS, AND THE SILENCE OF THE INDIGENOUS PROTAGONISM, STARTING FROM THE LIFE HISTORY, MEMORY AND THE LEGACY OF CACIQUE TUPINAMBÁ RESISTANCE. OUR GOAL WAS, THEREFORE, TO CREATE INSTITUTIONAL SPACES SO THAT INDIGENOUS VOICES COULD BE HEARD. IN ADDITION, THE FOCUS ON REGISTERING OTHER VOICES, DISSEMINATE OTHER HISTORIES, PUBLICIZE THE DESIRES AND EXPECTATIONS OF THE MOVEMENT'S MEMBERS THROUGH CACIQUE KAWANY LOURDES TUPINAMBÁ BIOGRAPHY MOVES TOWARDS RECENT DISCUSSIONS ON ANTHROPOLOGY ON DEMAND.
\end{abstract}




\section{KEYWORDS: INDIGENOUS HISTORY; ANTHROPOLOGY ON DEMAND; MEMORY}

\section{INTRODUÇÃO}

O presente trabalho é fruto de uma experiência etnográfica que teve como objetivo resgatar a memória, o protagonismo político, histórico e social da Cacique Kawany Lourdes Tupinambá. A partir da fala dessa liderança, perscrutamos colocar em evidencia a perspectiva de uma das componentes do Movimento dos Indígenas não Aldeados do Triângulo Mineiro e Alto Paranaíba - MInA. Vislumbramos assim, abrir portas para futuros trabalhos que tenha como objetivo adensar a discussão a partir de outras biografias sobre esses indígenas. Apesar da resistência do movimento, ainda hoje, deparam-se cada vez mais com poucos espaços para contar suas histórias. Nesse sentido, em conversas e diálogos com a Cacique e a partir de uma demanda conjunta decidimos então escrever um texto a "seis mãos" que pudesse dar conta dos seus anseios e de nossas prerrogativas enquanto antropólogas. Obviamente não se trata de uma visão hierarquizada e cartesiana, mas sim holística e total, um texto que conjuga ao mesmo tempo duas ações distintas, mas complementares, pois é tanto um texto com a liderança e sobre a liderança.

Pensar essas relações, o MInA, a memória e a história de vida da Cacique caminha em direção com as críticas pós-modernas, teorias pós-coloniais e decoloniais. É por isso que pensar os padrões de poder e a colonialidade do poder (QUIJANO, 2005) se torna algo inevitável.

A partir dessas reflexões, pretende-se por meio desse trabalho criar espaços institucionais afim de amplificar e ecoar as vozes subalternas (SPIVAK, 2010). Por isso, a intenção é dar destaque para sua voz na escrita desse texto, mas não só. Gostaríamos de agradecer e destacar que essa possibilidade foi sugerida pelo Prof. Dr. Daniel Munduruku ${ }^{1} \mathrm{em}$ uma conversa informal. Dessa forma, sugerimos que o relato gravado seja escutado ${ }^{2}$, pois

\footnotetext{
${ }^{1}$ Daniel Munduruku possui graduação em Filosofia pela Universidade Salesiana de Lorena (1989). É doutor em Educação pela Universidade de São Paulo. Tem experiência na área de Educação, com ênfase em Educação Indígena. É pós-doutor em Linguística com ênfase na Literatura Indígena, na Universidade Federal de São Carlos. É autor de 52 livros voltados para o público infantil, juvenil e educadores. É Comendador da Ordem do Mérito Cultural da Presidência da República desde 2006. Em 2013 recebeu a mesma condecoração na Ordem Grã-Cruz. É Diretor-Presidente do Instituto UKA - Casa dos Saberes Ancestrais. Recebeu diversos prêmios literários no Brasil e no exterior. É membro da Academia de Letras de Lorena.

${ }^{2}$ Com a intenção de dar destaque e promover a escuta literal dessa voz, segue link para acesso à gravação do relato da Cacique Tupinambá com as devidas ressalvas e cortes indicados pela liderança indígena afim de
} 
impressões, emoções e determinados sentimentos só serão captados pela voz, literal, da Cacique Tupinambá. Vozes que foram silenciadas e invisibilizadas como resultado de uma violência epistêmica relacionada ao projeto de constituir o sujeito colonial como outro, um outro dotado de uma história única contada pelos sujeitos colonizadores.

Por isso, o texto foi pensado por uma apresentação inicial e reflexões teóricas fomentadas pelo relato da Cacique Tupinambá. Após essas exposições, a fala da indígena toma cena ao descrer suas prerrogativas, pensamentos e sentimentos com suas próprias palavras, o fim do texto quem encerra também é ela. Essas inquietudes não serão passíveis de solução e nem é a proposta do texto. Mas como resultado de uma experimentação etnográfica que teve como propósito contribuir com essas novas formas de construção textual.

Dito isso, abrimos a sessão com uma frase de uma das indígenas do movimento.

"A história do oeste nunca foi contada pelo cavalo que carregava os cavaleiros" a frase identificada na animação "Spirit: o corcel indomável" foi trazida pela memória da indígena Sonia autodenominada Tapuia. A recordação se deu na plenária do Movimento dos Indígenas não Aldeados do Triângulo Mineiro e Alto Paranaíba - MInA - ocorrida na Oca, sede do movimento, localizada no Acampamento do Glória, município de Uberlândia - MG, no dia oito de Novembro de 2018 sobre a $6^{\text {a }}$ Conferência Nacional de Saúde Indígena ${ }^{3}$. Tal fala já reproduz as discussões que centram a análise no protagonismo indígena feitas por antropólogos, historiadores e também agora por pesquisadores indígenas.

A narrativa também pode ser pensada a partir do que W. Benjamin chamou de "história a contrapelos". Uma perspectiva analítica que dá relevância aos trajetos sociais, culturais e políticos de sujeitos historicamente marginalizados pelo processo de registro oficial. Essa analogia nos permite pensar exatamente o que a indígena Sonia Tapuia quis nos dizer com a história dos cavaleiros e não dos cavalos. Ao interpretarmos essa categoria analítica, assumimos a ideia de que a história a contrapelos, neste trabalho, se pauta não mais nos registros de fatos e eventos oriundos somente da história contada pelos cavaleiros, mas, sobretudo, dentro das envergaduras e quem sabe ferraduras sócio-históricas dos índios não aldeados, representados, pela narrativa da indígena.

\footnotetext{
preservar algumas temáticas que deveriam ficar circunscritas somente na escrita https://drive.google.com/file/d/1kaPiP286Y-3Wts56XQQYbEkpJhAhWx9j/view?usp=sharing

3 Na ocasião da plenária foi apresentado e discutido os eixos norteadores do documento orientador da $6^{\mathrm{a}}$ Conferência Nacional de Saúde Indígena. Dentro do diálogo e apresentação dos tópicos pertencentes a cada eixo, os indígenas, em coletivo, indicaram algumas demandas que atenderiam suas necessidades no contexto urbano.
} 
A afirmação permite ainda fazer uma rápida explicação sobre o título do trabalho. Tomar posse da história integra o relato ${ }^{4}$ da Cacique Tupinambá. Tal expressão ecoa o momento em que ela foi consagrada Cacique pelos membros do movimento por respeito a decisão da falecida Cacique Kaun Poty Guarani. Há um empoderamento nessa fala. Nesse cenário e a partir daquele ciclo que se iniciava ela se apropriava de outras formas de sua história, de sua cultura e sua vida em prol de uma luta por todos os indígenas que são membros do movimento, suspendendo a ideia de que os povos indígenas devam ser tutelados ou que no fim último não sabem contar sua própria história.

Tal termo empregado pela Cacique corrobora ainda para o que a escritora nigeriana Chimamanda Adichie (2010) entende como os "perigos da história única", locução que intitulou a palestra proferida por Adichie. O verbete se refere a criação de estereótipos e imagens genéricas que impõe determinados padrões de poder. Sobre como epistemologias etnocêntricas e evolucionistas impuseram a reprodução de determinados discursos e percepções, e como nós somos impressionáveis e vulneráveis frente a uma única versão da história.

O que notamos é que a fala da Cacique questiona esse movimento da história única como algo a ser revisitado não só no plano contemporâneo, mas também dentro da história dos índios no Brasil. Isso porque, grande parte da invisibilidade cultural, econômica e histórica dos índios hoje, na verdade, tem suas raízes no processo histórico do contato. Uma vez que os portugueses para lidar com a diversidade do panorama etnográfico das populações indígenas acabaram por criar uma história única, unilateral, forjando e construindo dualidades e hierarquias. Por isso, imagens associadas a um horror sangrento, guerras, vinganças, animalidades, selvageria e barbárie foram geradas, para justificar as inúmeras violências cometidas contra essas populações.

\section{REPENSANDO A HISTÓRIA DO CONTATO}

Essa história dos índios no Brasil, portanto, foi marcada por uma visão classificatória que enxergou esses indígenas sob dicotomias e hierarquias. A primeira hierarquia e geração de imagens genéricas e cristalizadas estão no imaginário Tupi/Tapuia encontrado nos

\footnotetext{
${ }^{4} \mathrm{O}$ relato da Cacique Tupinambá foi gravado já que a indígena não tem muita familiaridade com a escrita. Toda a transcrição feita posteriormente, bem como o texto todo, foram lidos várias vezes, afim de confirmar seu relato pessoal. Também afim de tornar ciente a Cacique, enquanto autora, com todo o conteúdo e reflexões que foram feitas a partir de sua história. .
} 
primeiros relatos sobre o Brasil. Os tupi eram os povos amigos, mansos, aliados, aldeados e moradores do litoral. Os tapuia eram o simétrico oposto, selvagens, bárbaros, inimigos, nômades e habitantes do sertão (AMANTINO, 2001). Pensando os lugares que esses povos ocuparam no imaginário, cria-se uma outra dualidade: litoral/sertão.

O litoral civilizado se contrastava com o sertão primitivo, lugar onde a civilização ainda não teve alcance. No sertão o tempo é congelado, como se a história não o afetasse e ali não se encontrasse, um sertão que foi também construído, que se tornou herança do colonizador, no qual o colonizado nunca foi ouvido do que pra ele aquele espaço significa (SENA, 2011).

Essa é a falha da única história, pois ela

[...] cria estereótipos, e o problema com estereótipos não é que eles sejam mentira mas que eles sejam incompletos. Eles fazem uma história tornar-se a única história... comece uma história com as flechas dos nativos americanos e não com a chegada dos britânicos, e você tem uma história totalmente diferente. (ADICHIE, 2010)

Por isso, os indígenas no Brasil não eram vistos como sujeitos dotados de agência. Quando, oportunamente é construída a noção da necessidade da tutela. Tal construção inferioriza os indígenas, como se na realidade eles não fossem capazes de administrar suas vidas, histórias e variadas formas de lidar com a alteridade. Essa relação de tutela e "pacificação", na visão de alguns indígenas, como Ailton Krenak (SILVA, 1994), foi sinônimo de extermínio, pois muitos indígenas foram explorados e manipuladas nessa relação afim de serem dominados e violentados.

Com o objetivo de entender as consequências históricas proveniente dos anos de contato, a etnologia indígena, na década de 1960 e 1970, constrói três linhas de pensamento. O conceito de aculturação cunhado por Eduardo Galvão (1979) explicaria as consequências culturais e históricas que as populações indígenas iriam passar por intermédio do processo do contato. Assim, povos indígenas, paulatinamente iriam assimilar total ou parcialmente os costumes ocidentais no seu modo de viver. Darcy Ribeiro (1970), por seu turno, ao trazer a ideia de transfiguração étnica diz que nenhum índio vira civilizado, o que acontece é que o contato promove a morte de alguns povos indígenas e o no lugar deles vão surgindo outros grupos, logo não há uma conversão, como tampouco assimilação. Teríamos, na verdade, uma integração inevitável, a partir da qual os indignas não perderiam sua identidade, porém se adequariam aos costumes de um ambiente que lhe seria hostil. Segundo Cardoso de Oliveira 
(1963) essas premissas daria um tom de equilíbrio e consenso nas relações de contato, por isso, ele mostra o revés. Numa situação de contato o que se tem na verdade são conflitos e representações de dissenso, culminando, pois, no que ele vem a chamar de fricção interétnica. Tal conceito apontava também para a descaracterização das sociedades indígenas, na medida em que seriam incorporadas as economias regionais.

Apesar das grandes contribuições etnográficas que tais formulações permitiram desenvolver em inúmeros trabalhos, não devemos deixar de notar que elas, no limite, entendem os indígenas, suas culturas e suas histórias, pela lente da negação que perderiam seus costumes e estariam destinados ao desaparecimento ou ao fracasso enquanto população. Seu destino seria um só: o fim. Essas teorias não davam ênfase as diferentes formas de resistência e luta que poderia existir dentro das comunidades indígenas, na verdade, não capturaram a ações políticas desenvolvidas no cerne do movimento indígena de reaver suas tradições "perdidas" ou o que alguns antropólogos viriam a denominar nas décadas seguintes como o estudo das emergências étnicas ou processo de etnogênese.

O conceito de etnogênese é um bom exemplo, portanto, para essa mudança de perspectiva. O estudo das emergências começa, sobretudo, nos anos 1970 e 1980 (OLIVEIRA FILHO, 1998; ARRUTI, 2001; 1997, 2006), desde então a pesquisa antropológica e histórica vem acompanhando uma multiplicação desse movimento com demandas por reconhecimento em mais de 50 grupos, concentrados, especialmente, na região norte e nordeste (ARRUTI, 2006). Podemos associar esse aumento pelas diretrizes da constituição de 1988, que possibilita aos "remanescentes indígenas" a retomada de suas terras e o reconhecimento de suas identidades.

Notamos que esse processo de emergência étnica trouxe consigo a construção de categorias e classificações sociais cujo objetivo era o de apresentar um processo histórico e social iniciado pelos grupos do Nordeste, utilizando o termo remanescências, ou, índios em processo de etnogênese (ARRUTI, 2006). Consoante a Maria Leônia Chaves Resende (2008), vários grupos, que tenham costumes, vivências e tradições muito próximas a seus grupos originários, mesmo com a ruptura temporal e espacial das relações podem construir, significar, desconstruir e ressignificar suas identidades. Isto é, a etnogênese é a "expressão de um povo que em condições adversas de dominação e experienciando longos anos de conflitos, procuram 'recriar' seus laços culturais" (RESENDE, p. 20, 2008). Trocando em miúdos, se trata de um processo, um percurso criativo inventado, ou melhor, construído por determinados 


\section{Nanduty}

grupos, seja indígenas ou afro-americanos, frente ao etnocídio e outros tipos de confrontos (MONTEIRO, 2001; HILL, 2006)

Por isso, um trabalho que parte do conceito de etnogênese deve salientar que esse processo histórico e social é sujeito a uma constante dinamização e ressignificação dos costumes, logo, evocar a ideia de grupo étnico como a cristalização ou essencialização de elementos, torna-se um risco para a pesquisa. Assumir identidade e cultura não como categorias fixas é fundamental para recuperá-las no processo histórico, numa construção dinâmica e flexível. A cultura, desse modo, não é apreendida como algo cristalizador e estanque no pertencimento do indivíduo a um grupo étnico, esses sujeitos constroem e reconstroem suas identidades a partir das experiências compartilhadas (RESENDE, 2003).

\section{O MINA, A MEMÓRIA E UMA ANTROPOLOGIA POR DEMANDA}

Com essas discussões em ebulição e o contato próximo que temos junto ao MInA Movimento dos Indígenas não Aldeados do Triângulo Mineiro e Alto Paranaíba - surge a ideia de convidar a liderança indígena que representa os integrantes do movimento para autoria desse trabalho.

Há algum tempo acompanhamos a demanda desse movimento dos Indígenas não Aldeados do Triangulo Mineiro sob a figura falecida Cacique Kaun Poty Guarani. Entretanto com a morte dessa liderança passamos a observar a rotação representativa dentro do movimento. Assim, em conversas e diálogos com a nova Cacique e a partir de uma demanda conjunta decidimos então como dito no início desse trabalho escrever um texto a "seis mãos". Para isso, fizemos uso de um gravador para que a fala da Cacique alcance um patamar de reconhecimento, se constituindo enquanto um documento que pode ser consultado por pesquisadores e pela comunidade que, liderada por ela, o gerou (CORRÊA, 1996; FREITAS, 2002).

Cacique Kawany Lourdes Tupinambá, desde maio de 2018 assumiu o papel de liderança do movimento, legado deixado pela já falecida Cacique Kaun Poty Guarani que esteve à frente do movimento desde o ano de 2006, ano de sua fundação. O MInA mantem sede na Oca construída no Acampamento do Glória, antes lugar de ocupação do Movimento 
dos Sem Teto do Brasil (MSTB), que hoje está passando por um processo de regularização dos imóveis no município de Uberlândia - MG.

É possível identificar uma relação muito forte dos membros do movimento com essa materialidade. O espaço material que sedia o MInA é visto como "coisa" (INGOLD, 2012), não apenas um objeto ou cultura material desses indígenas, mas uma materialidade que dotada de movimento, agência e fluxos incita memórias, sentimentos, simbolismos e práticas únicas. Isso transparece em parte da narrativa da Cacique Tupinambá: o MInA é um movimento de pessoas, um movimento dos indígenas e a Oca, o sentimento dela pra mim e eu creio que pra todos os indígenas é um sentimento de que nós perdemos nossa origem, nossa casa, vivência, onde nós criamos, nós vivíamos. Oca significa muito, ela pra nós é um santuário, significa família, cultura, passado.

O Movimento dos Indígenas não Aldeados do Triângulo Mineiro e Alto Paranaíba MInA - é composto por várias famílias que se encontram divididas em dez famílias na cidade de Santa Vitória, quinze em Ituiutaba, onze em Campina Verde e vinte na cidade de Araxá (FILHO; PEDROSO, 2010). Infelizmente esses núcleos por estarem à revelia da imagem e identidade cristalizada do indígena ídilico são colocados e tratados no bojo e na condição de pobres urbanos em geral.

A sede do movimento, em Uberlândia, se encontra num acampamento do Glória composto em sua maioria por moradores do MSTB, ratificando essa ideia de que esses indígenas não aldeados são vistos pelas autoridades locais como menos índios, índios misturados e até mesmo índios "paraguaios". O desafio que se encontra hoje é o de reconhecimento de sua memória enquanto grupo, das suas terras ancestrais e da identidade indígena.

Esse movimento de resgate de suas tradições está continuamente relacionado ao trabalho da memória, na medida em que o panorama de mudança futura tem a possibilidade de alterar, manter, significar e ressignificar narrativas pretéritas, "de modo a tê-las até mesmo como instrumentos da ação política” (GODOI, 1999, p. 29). E é justamente essa ação política que se torna o objetivo das lideranças para com as autoridades locais. É um movimento de produção e reprodução da sua cultura aliada a ação política a partir da colaboração das famílias do Triângulo Mineiro e Alto Paranaíba em parceria com antropólogos e historiadores da Universidade Federal de Uberlândia. No âmbito dessa colaboração institucional que ressaltamos que o presente trabalho se inscreve, como dito, na Antropologia por demanda. 
Em uma perspectiva pós-colonial e decolonial, a noção de uma Antropologia por demanda tem sido o referencial teórico-metodológico utilizado para o desenvolvimento dessa pesquisa. Dentro dessa concepção deve-se primar por uma Antropologia que consiga responder não só nossas perguntas enquanto pesquisadores, mas que responda às indagações dos indígenas e que possam servi-los como uma caixa de ferramentas (SEGATO, 2012) em suas lutas e reivindicações no presente.

Uma Antropologia atenta, engajada, voltada para o bem estar dos sujeitos. Uma mudança e rotação de perspectiva. Não mais produzir conhecimento sobre o outro, mas para o outro. Por isso, o recorte da história de vida da Cacique foi apontado pela própria indígena, que tem nessa transferência de legado da Cacique Kaun Poty Guarani do papel de liderança, parte fundamental de sua história e missão de sua vida "até atravessar o grande rio", cena que retrata a passagem de vida para a morte que estará descrita no seu relato pessoal.

Tal foco, invoca o conceito de etnicidade (CUNHA, 2014) trabalhado no artigo enquanto diálogo da cultura e ação política do grupo étnico. O engajamento político do movimento, bem como o discurso de fortalecimento e reconhecimento étnico reforça e é a demonstração prática dessa discussão teórica e de sua cultura em contraste com a alteridade.

A narrativa construída pela Cacique Kawany Lourdes Tupinambá caminha em direção a essas novas perspectivas inaugurada pelas discussões desenvolvidas pela história indígena dos anos 1980 (MONTEIRO, 2001; OLIVEIRA FILHO, 1998). O discurso reforça o quanto esses indígenas são sujeitos ativos social e politicamente, e portanto, o quanto são consciente de sua ação política no mundo contemporâneo.

A liderança herdada pela Cacique Tupinambá torna a indígena responsável por representar cerca de oitenta indígenas de várias etnias em busca de reconhecimento por parte das autoridades competentes. Hoje a maior demanda e sonho do MInA é a destinação de área pública para território indígena em área urbana com nascente e vegetação nativa para criação de aldeia com saneamento adequado, além da garantia de que nesse território as famílias tenham condições de gerar trabalho e renda a partir dos conhecimentos tradicionais produzindo alimentos e comercializando os excedentes e que ainda possam ter acesso garantido a saúde psicossocial afim de fortalecer a relação dos indígenas com a natureza e o território.

O relato pela saúde psicossocial de qualidade específica para os indígenas advém do crescente número de indígenas que vive no mundo da dependência química, alcoolismo e 
suicídio. Tais fatos resultam desse prejuízo psicológico resultado da colonização, o que nos recorda Fanon (2008), que em sua celebre obra Mascaras Negras, Peles brancas, faz uma análise ímpar do prejuízo psicológico do colonialismo para a população negra. Tal reflexão, se lançada ao mundo indígena, demonstra o quanto o colonialismo e exploração não se deu apenas no âmbito econômico ou político, mas também psicológico e social.

A biografia da Cacique Tupinambá descrita no texto de sua autoria reforça essa afirmação. O relato nos mostra o quanto esses indígenas que vivem em contexto urbano sem terras demarcadas se tornam dependentes químicos, provocam dores e bloqueios emocionais nos seus povos, derivado dessa desterritorialização forçada de suas terras pretéritas. Reforço que essa desterritorialização e posterior reterritorialização não se trata de territórios físicos e fixos, mas sim de subjetividades, existências, o que impulsiona pensar o território como múltiplo, dinâmico, pleno de saberes, memorias e lutas.

Desse modo, é possível identificar que toda violência sofrida num passado histórico por esses indígenas se perpetua ainda hoje com prejuízos de todas as formas. Esse padrão de poder e colonialidade (QUIJANO, 2005) que foi imposto desde a invasão de suas terras se desdobra ainda hoje em violências físicas, psicológicas, emocionais, territoriais e epistêmicas. Como resultado dessa violência, a história do Brasil nunca foi vista sob a perspectiva dos indígenas, apenas dos colonizadores e vencedores dessa história. O intuito do trabalho ao ser escrito de forma colaborativa e/ou conjunta, é dar destaque e criar condições institucionais para que esses indígenas sejam ouvidos e possam escrever suas próprias histórias, já que essa tem sido uma demanda emergencial desses povos.

Além disso, o destaque e a opção pela história de vida da Cacique Tupinambá, no qual ela preferiu dar relevância a seu legado como liderança do movimento, vem da força do projeto coordenado pelo Prof. Dr. Joao Pacheco de Oliveira, antropólogo e Professor Titular da Universidade Federal do Rio de Janeiro/UFRJ. O projeto intitulado "Os Brasis e suas memórias: os indígenas na formação nacional" tem a proposta de produzir e divulgar dados e interpretações novas sobre a continuada e persistente presença da população autóctone não só no período colonial e no século XIX, mas no Brasil Republicano e atual afim de viabilizar outra narrativa sobre o Brasil. Essa construção de outras histórias será feira por meio da construção de biografias indígenas.

A partir da história de vida dessas pessoas, aqui no caso da Cacique Tupinambá, escolhida para compor tal fato, pretende-se acessar outras histórias de vida, memórias, 
lugares e com isso contribuir nesse quebra-cabeça dessa nova história que quer se constituir sob novo olhar e narrativa.

O projeto também tem o intuito de desmistificar bem como desnaturalizar estereótipos e imagens genéricas que foram atribuídos de maneira universal aos indígenas, o que inviabiliza a multiplicidade e a enorme diversidade sociocultural dos indígenas no Brasil conforme indica próprio relato da Cacique que segue completo durante sua narrativa: porque muita gente acha que o índio é só nas aldeia, só na mata, nus, o índio. $\mathrm{O}$ brasileiro, ele não é só brasileiro aqui no Brasil, ele é brasileiro nos Estados Unidos, ele é brasileiro aonde ele chegar. Então o índio, ele não é índio só nas mata, só na cultura dele lá, nu ou fazendo as coisa dele lá dentro, ele é índio aonde ele chegar, em qualquer território.

Ressaltamos também a importância das mulheres indígenas como escritoras e pesquisadoras, já que em grande parte, essa hierarquia de gênero ainda parece se manter na produção científica indígena, criando a ideia de que as próprias teorias e discursos são dotados de gênero, no caso o masculino (LUTZ, 1995).

Muitas vezes o trabalho escrito por mulheres tem sido visto sob a ótica menos racional e objetiva e mais emocional e subjetivo. Por isso, a escrita feminina, seja antropológica ou não, muitas vezes tem um prestígio menor, inclusive sendo marginalizada nos meios científicos. Com isso vemos o quanto a colonialidade do poder e esses padrões hierarquizantes atuam também por meio do gênero. Como a intensão do artigo é trabalhar com a criação de novas epistemologias e novas possibilidades de produção colaborativa com os sujeitos de pesquisa, essa escolha de produção textual pretende criar outras ficções persuasivas acerca do Brasil e da presença e papéis dos indígenas nessa história.

O propósito é criar uma ficção que no contexto contemporâneo das discussões antropológicas, a partir das perspectivas pós-coloniais e decoloniais se torne crível, no qual "a questão não é simplesmente como trazer cenas à vida, mas como trazer vida as ideias" (STRATHERN, 2014, p. 175).

Dessa forma, segue o relato dotado de emoção, memória, história, resistência e vida da Cacique Kawany Lourdes Tupinambá, no qual ela evidencia aspectos e fragmentos que viabiliza outras formas de diálogo e em especial, como na sua história de vida, essa adoção simbólica da Cacique Kaun Poty Guarani e o legado deixado por ela revela aspectos importante dessas histórias e suas aspirações futuras para o MInA. 
A partir de então, a palavra é dela, somente dela, que deu forma ao texto, pois suas palavras foram as geradoras de todas as reflexões promovidas durante a escrita. Além disso, ela conclui com muita emoção o texto, a partir da memória ativada por uma citação da falecida Cacique Kaun Poty Guarani, a qual ela termina com uma perspectiva complementar própria, trazendo a noção de continuidade e de então o começo de um fim. Reforçamos o quanto foi grandioso esse trabalho conjunto, e o quanto aprendemos nessa jornada sublime de construção de outras histórias ao seu lado Maria de Lourdes Lima Soares, Cacique Kawany Lourdes Tupinambá.

\section{MARIA DE LOURDES LIMA SOARES, CACIQUE KAWANY LOURDES TUPINAMBÁ}

Meu nome é Maria de Lourdes Lima Soares, nome indígena Kawany Lourdes Tupinambá. Sou da região do Ceará, região ali de Barbalha, Juazeiro, Missão Velha, Crato. Sou de uma etnia indígena, meus antepassados todos eram indígenas e lá é região indígena, então eu estou aqui porque tomaram tudo que era nosso. Meus antepassados perderam as terras deles e foram trabalhar, uns com coronéis, outros foram viver uma vida ruralista.

Eu fui criada por meus avos porque meu pai morreu eu tinha 11 meses e entregou eu para os meu avos, para minha madrinha me criar. Minha mãe foi vendida a pau de arara, veio embora pra Rio Verde, Goiás, em Santa Helena, onde ela foi vendida e escravizada por um turco, uma família de turco. E eu fui criada e registrada como filha dos meus avós. Na idade de 12 anos foi que eu descobri que eu não era filha, era neta, então foi onde eu comecei a curiosidade pra conhecer minha mãe e comecei a entrar em contato, fiquei rebelde na adolescência, entrei na rebeldia e com quatorze anos fizeram meu casamento com um cara a força, eu casei e foi a destruição da minha vida.

Eu casei na igreja de São José em Missão Velha. Na minha vinda para cá, depois que eu me casei e destruí minha vida, entrei na curiosidade de conhecer mamãe, eu consegui um endereço e liguei aqui pra CTBC daqui de Uberlândia e aí foi quando eu descobri o endereço da minha mãe. Entrei em contato com a minha irmã pela primeira vez. Ela mandou o dinheiro, pela primeira vez não deu pra vir, aí eu já era mãe solteira, tava com uma filha nos braços, porque o casamento lá não deu certo, eu descobri que ele 
roubava na roça dos outros pra me dar comida e eu não aceitei, eu não gosto, não que eu sou mais honesta que todo mundo, mas eu não fui criada assim e ali ele me trancou dentro do porão quando me encontraram eu tava quase morta. Dei amnesia, fiquei internada, com quinze anos. Bebi muita cachaça e fumando, foi quando fiquei doente, dei depressão, foi quando fiquei internada nove meses numa clínica. Aí quando eu superei foi quando eu fui trabalhar na minha vida novamente e fui mãe com vinte e um anos, mãe solteira. Foi aonde eu vim. Mamãe mandou a primeira vez o dinheiro não deu, a segunda não deu, a terceira deu e eu vim me embora. No ano de 1990 eu cheguei aqui, saí de lá do Ceará no dia 18 de maio de 1990 e cheguei aqui no dia 20 de 1990 aqui em Uberlândia.

E começou minha história. Dez dias de viagem. Um enteado da mamãe veio visitar ela, ele era descendente de Kayapó e aí foi que ele casou comigo e nós tivemos 3 filhos. Porque eu já vim de lá grávida, do mesmo pai da minha menina e ele assumiu meu menino. Tivemos três filhos mais nos separamos porque ele não gostava de trabalhar e eu que tinha que trabalhar pra manter casa e aquilo foi me cansando, sofri muito eu tive que pedi nas ruas para os meus filhos comerem, tive que trabalhar, eu dei anemia crônica, eu fiquei muito doente. Uma história de vida muito sofrida, mas pra mim eu não levo como sofrimento, é superação de vida e aprendizagem.

E quando foi no ano de 2004, mais ou menos, eu conheci a Cacique Poty, 2004, 2005 por aí e ela soube através de uma amiga minha que eu era indígena. A primeira vez que eu vi ela e tive o contato mesmo com indígena depois de tanto tempo, e ela foi até minha casa e eu contei a história pra ela, ela nos resgatou. Eu e minha família que somos Tupinambá, somos mais de duzentas pessoas hoje.

A minha irmã mais velha já é quase bisa já, já é bisa, ela já e quase tataravó. Então começou, no ano de 2006 nós entramos na universidade pela primeira vez pela ENECS aonde teve o primeiro encontro de nações e nós expomos nossas coisas indígenas, pudemos usar nosso colares, nossa comida, nossa cultura, nosso tudo.

E foi a primeira assembleia aonde foi tirada a comissão indígena e nasceu o MInA, Movimento dos Indígenas não Aldeados do Triangulo Mineiro e Alto Paranaíba, Brasil e aí começou a nossa história com a Cacique Kaun Poty Guarani, nome brasileiro Maria Virginita de Oliveira.

E aí foi uma história que começou. O ano passado ela faleceu, nós dizemos que ela passou o grande rio. Eu não sabia, foi uma grande surpresa pra mim foi quando eu soube 
que ela deixou o legado, a história dela pra mim. No dia do sepultamento dela que nós íamos lá na praça ao lado do terminal central quando a Sonia, eu nem conhecia, não tinha conhecimento da Sonia, meu marido que tinha mais conhecimento com ela porque devido eu ter ficado muito doente de trombose eu quase não ia no movimento. Então meu marido que vinha fazer serviço aqui na Oca, pra capinar, pra cuidar do terreno pra Poty e a Sonia tinha mais contato com ele.

Aí ela chegou em mim e perguntou: você é a Lourdes? Eu falei sim. Irma da Cândida? Sim. Aí ela falou: o legado da Poty, é seu, da Cacique. Eu achei um absurdo, porque eu não sabia o que era legado. E eu: o que que é legado? Não, não, eu não vou pagar essa conta não. Ela olhou pra mim e falou: você não sabe o que que é legado? Eu disse não, não sei, aí ela diz o legado é a história da Poty, ela declarou você como filha dela e você vai assumir... eu digo não é hora disso e eu não quero nem saber, por favor.

Aí ela parou. Lá no velório tinha a representante da segurança dela (Cacique Kaun Poty Guarani), porque ela foi ameaçada de morte aqui, aí ela foi atrás dos órgãos federais, ela tava sob proteção da Secretaria de Estado dos Direitos Humanos, que tava representando o Governador, foi o que ela me falou. Ela lá perguntou pra alguém quem era a Maria de Lourdes, aí as pessoas me mostraram, eu tava chorando porque tava perto da hora do enterro me lembrando de como eu conheci ela, de como ela entrou pela primeira vez na minha casa. De como ela nos resgatou, as poesia, as histórias, a "brabeza" dela, porque ela era muito "braba" tinha hora que era até petulante mesmo, ela era terrível.

Eu lembrando e chorando, lembrando e chorando, pensando acabou a história. Eu jamais imaginava que a história poderia retornar. Enfim, a moça chegou e perguntou você que é a Maria de Lourdes? Eu disse sim. Ela: o legado da Poty é seu. Eu disse: de novo essa história de legado? Meu deus, eu não to com condição, eu não quero saber, eu nem sei o que que é legado. Ela disse: você é a nova Cacique, ela declarou você como filha e eu vou fazer parte da sua segurança também. Aí eu disse não é hora disso, enfim, conversei e fui fazer o ritual pra hora do sepultamento. Logo em seguida viemos embora. Eu realizei a missa de sétimo dia, fiz uma reunião, tenho tudo fotografado, tudo arrumando.

Aí um mês depois fizemos uma nova reunião, aí eu falei eu não vou ser Cacique, eu não quero. Porque eu não queria, porque era uma responsabilidade muito grande, eu via o que ela sofria, eu via que tudo ficava nela, ela chorava muito, ela era muito confidente 
comigo, ela chegava na minha casa, as vezes caindo de fome, em situação que eu ficava triste. Às vezes eu vinha aqui, encontrava ela doente, e eu via o que todo mundo falava dela, aí eu dizia: eu não quero ser Cacique. Eu não quero, mandei os outros candidatarem, e disse não quero. Fui pra cozinha arrumar os trem, quando de repente eles gritaram lá: Viva a Cacique! E eu digo: mas eu não falei que não era eu. A Sonia veio e falou não pode, uma vez que um Cacique fala.

Aí fui eleita na Assembleia em respeito a decisão da Cacique. Porque que deixa um legado? Eu nem conhecia assim esse direito de legado. Ela teve quatorze abortos, mas nenhum vingou e só um Cacique pode declarar um filho. É herança de pai pra filho, e ela me declarou como filha. E até hoje, agora que to começando a pisar no chão, porque antes eu não aceitava, eu não aceitava eu vim pra cá. Eu digo, não. Puis pra procurar os irmãos dela, a Leila entrou em contato, foram no $\mathrm{W}^{5}$. eles falaram que não queriam saber disso aqui. Eles não abraçavam a causa indígena antes, nem queria saber. Foi quando W. veio e entregou a história no dia que ganhei como Cacique, e disse agora minha querida você é a nova Cacique e eu to entregando o que os irmão dela entregaram pra mim e eu to devolvendo pra você.

A história, tudo, entregou uma carta que eu tenho. Tem uma parte que eu não gosto muito de estar falando, coloquei o G. pra morar aqui e ele roubou a Oca. Ele encheu aqui de entulho, virou um problema. Quase que derrubaram a Oca no dia 19 de Abril, ele espantou todo mundo. Falava com as mulheres palavra de horror, ele é machista. Aí foi quando chegaram em mim e falaram, se a senhora não vier pra cá, nós vamos tacar fogo nisso tudo.

Que eu fiz? Foi fazer oração, e disse: Senhor, o legado é meu, eu não corri atrás de nada disso, então se o senhor diz que é meu então está nas suas mãos, eu não vou brigar por isso, não vou entrar na justiça. Aí eu peguei e fiquei quieta. Um dia, sem nem esperar ele foi lá e levou a chave daqui, tenho tudo anotado, arrumado, em maio desse ano.

E aí eu vim embora pra cá. Que eu fiz? Disse pro meu marido, chegou a hora, não tem como nós não irmos, Deus deu a resposta. Então meu marido já veio, já dormiu a noite. Quando eu cheguei não tinha nada, ele levou tudo daqui, e a Poty deixou a casa montada, roubaram muita coisa dos artesanatos dela.

O H.G estava vendendo tudo, até o lote do espaço, no dia que a Poty morreu. Quando chegamos aqui, no dia que ela morreu ele já sabia da morte dela. Minha irmã já sabia e disse, ele ta lá, ta vendendo tudo. Quando chegamos aqui tava o carro que ele tava fazendo negócio,

\footnotetext{
${ }^{5}$ Alguns nomes estão representados por letras afim de preservar a identidade das pessoas envolvidas.
} 
os povos aqui, as coisas tudo empacotadas, os trem de documento, se eu tenho alguma coisa de documento eu peguei no lixo. Ele jogou tudo fora, já tinha levado televisão, eletrodoméstico, tinha levado tudo.

Não só ele, muita gente levou, aí eu cheguei e disse na linguagem indígena: olá tudo bem? Ele ficou muito amarelo e disse: você que é a Lourdes? Eu disse sou. As pessoas disseram: você chegou na hora certa, ele está vendendo aqui tudo. Aí eu disse quem ta vendendo? Aí eu cheguei e perguntei, quem ta trocando aí?? Aí eu cheguei e peguei no pau da Oca e falei: AQUI NÃO É MEU, AQUI NÃO É SEU, AQUI É DO MINA, E A PARTIR DE HOJE CHAMARÁ MEMORIAL CACIQUE KAUN POTY GUARANI ${ }^{6}$.

Eu gritei, não sei de onde veio: a partir de hoje esse lugar chamará Memorial Cacique Kaun Poty Guarani. Aí ele (H.G) disse: mas isso aqui é meu, eu disse o que é seu é aquilo ali, minha irmã gritou, o que é seu é essa igreja, ela tava chorando muito, nem enfrentou ele porque tava muito abatida. Aquilo era seu e você vendeu. Aí eu fiquei. O marido da presidente do bairro veio pra tomar, se ta vendendo não vai vender, vai devolver pra Associação. Aí eu disse não, eu me responsabilizo até outro Cacique ser eleito, eu fico como coordenadora, porque ela já ia deixar eu como coordenadora, ela já tinha dito pra mim. Aí eu fiquei, no dia que a máquina ia passar aqui ele lembrou, no dia que a Poty morreu, o rapaz tava vendendo tudo, ela nem tinha esfriado, eu tive que vim aqui, uma moça veio e gritou: aqui não é meu, aqui não é seu, aqui é dos indígenas não aldeados, aqui é uma área indígena e a partir de hoje chamará Memorial Cacique Kaun Poty Guarani.

Eu disse, você lembra essa moça que gritou? Lembro, muito "braba". Eu disse, aquela moça era eu. Ele: era você Cacique? Mas você ficou "braba" demais, parece que você veio voando. Mas ele ia vender tudo, tinha arrumado um caminhão, estava tudo empacotado pra levar, ele já ia embora pro velório dela com tudo.

Depois teve o enterro, nós viemos, eu liguei pra ele vir pra Missa, ele disse pra mim muito bruto: de vocês eu quero distância, não quero conversa com vocês, você mais sua irmã eu quero que vocês sumam da minha vida, vocês acabaram com minha vida. Não queria saber do movimento mais, depois que tudo isso passou, ele viu o movimento erguer, ta engatinhando, mas está aí, eu tenho ido nas escolas, na UFU eles tem me procurado, o trabalho da benzeção que antes nem tinha isso, ninguém benzia aqui, todo mundo ta achando

\footnotetext{
${ }^{6}$ A caixa alta foi com a intenção de demonstrar a entonação e intensidade utilizada pela Cacique Tupinambá durante a descrição do relato.
} 
novidade, tem os xaropes, os remédios para as crianças, eu não cobro nada, tudo, tudo de graça.

$\mathrm{Na}$ escola eu falo da cultura, da alimentação, porque eu era coordenadora da alimentação indígena, eu vinha fazer as comidas, que é comida indígena, a história minha, a resistência, a gente fala disso. Tem muitas coisas pra gente conseguir, como uma área, que é o que a gente mais sonha, que era o sonho dela.

Aí já, depois que eu entrei, quando eu tomei posse da história ${ }^{7}$, a primeira coisa que eu pensei foi isso, eu pensei como vou chegar nos lugares e eu não sou Cacique? Aí chegou um papel pra ela, que ela tinha reivindicado terra pra gente plantar, aí me procuraram e fui no Ministério Público Estadual, eu mais vinte pessoas. Ela já tinha morrido, foi quando ele negou e falaram pra mim lá que eu tinha que entrar diretamente no Federal, eu tinha que reivindicar. Eu digo: eu posso fazer isso? Eles falaram pode. Aí já através disso eles já entraram com a Dra. Neiva, uma semana depois entrou em contato comigo, aí já entrou o processo pra reconhecer e colocar o nome indígena na identidade.

Foi onde dia vinte e seis de março teve a audiência ${ }^{8}$, que a gente já ganhou a causa e estamos esperando o documento. Como eu posso chegar num órgão federal, público e falo que eu sou uma Cacique ou uma indígena se eu não tenho documento? É o meu documento indígena, é a minha identidade. A minha identidade indígena. To representando e mostrando no documento quem eu sou, porque muita gente acha que o índio é só nas aldeias, só na mata, nus, o índio. O brasileiro, ele não é só brasileiro aqui no Brasil, ele é brasileiro nos Estados Unidos, ele é brasileiro aonde ele chegar. Então o índio, ele não é índio só nas matas, só na cultura dele lá, nu ou fazendo as coisas dele lá dentro, ele é índio aonde ele chegar, em qualquer território.

O maior sonho é ter nossa terra pra plantar, colher, ver nossas crianças fora das droga, porque o maior índice dos nossos jovem é a doença da droga, o vício. Eles tão disponíveis na droga e marginalidade, eu mesmo tenho sofrido com esse índice. Criei meus filhos muito bem criado mesmo, honesto, mesmo ele usando droga, é muito honesto, olha no olho, e isso tem

\footnotetext{
${ }^{7}$ Momento do relato que inspirou o título do texto.

${ }^{8}$ Audiência referente ao Processo n ${ }^{\circ}$ 1.22.026.000177/2017-51, instaurado com o objetivo de acompanhar os desdobramentos do Projeto "Índios do Triângulo" do Escritório de Assessoria Jurídica Popular (ESAJUP - UFU) coordenado pela Prof. Neiva Flávia de Oliveira (FADIR/UFU) e tomar as providências extrajudiciais ou judiciais que se fizerem necessárias para o regular exercício do direito da população indígena local de ter sua etnia registrada em seus documentos pessoais.
} 


\section{Nanduty}

me causando muito, e o que eu vejo os outros, a cachaça, o álcool que tem acabado com as famílias.

Eu vejo que a Cacique sempre teve um carinho especial comigo, mas eu achava, eu tinha ciúme dela com a minha irmã, eu achava que ela gostava mais da minha irmã, mas ela sempre, eu não observava, ela sempre tinha mais um carinho especial comigo, ela danava, ela brigava com os outros, comigo ela já me tratava diferente, ela chegava na minha casa. Eu me lembro como se fosse hoje, meus meninos já chegavam, "a vó" ela abraçava meus meninos, meus meninos chamam ela de avó, "a vó invém" e ela chegava punha a cadeirinha, quando ela chegava meu marido já corria, ela adorava chegar lá em casa pra comer ou a tapioca ou cuscuz e ela falava. Ela conversava, as coisas íntimas dela, a história dela ela me contava, quando ninguém nem sabia na época, ninguém, ninguém mesmo. Quando ela chegou e eu revelei, eu tive o dom assim, porque eu tenho um dom, assim de ver as coisas. Eu olhei pra ela e falei: você não tem casa mais em Ituiutaba. Ela assustou, ela assustou. Ela disse nossa minha "fia", eu não contei isso pra ninguém, eu sei que você tem seus poderes. Ela disse, isso é verdade, ela chorou muito e me contou, que passou a casa pro H.G. Eu tenho esse documento em mão dessa doação comigo. E é uma história muito dolorida. (Emocionada) O que mais me emociona é saber que ela me teve como filha, porque eu fui criada esperando o carinho de uma mãe, carinho de família. Eu fui criada muito dura, e nenhum da minha família nunca teve esse carinho por mim.

E ela tem falado isso, na espiritualidade ela pediu, vieram me dar o recado, que ela pediu que é pra me passar chamar ela de mamãe. Eu não sei nem como expressar sem ter uma lagrima nos olhos do carinho que ela tinha por mim, de me declarar como filha, ela sempre me dizia pra mim que eu era especial pra ela, mas eu não entendia. Não é porque ela deixou isso, eu não sou materialista, eu custei a vim pra cá, custei mesmo a aceitar vir pra cá, porque eu sou uma pessoa que eu acredito que é meu aquilo que eu lutei pra me ter, aquilo que ou comprei ou alguém chegou e disse assim: é seu. Então eu não queria aceitar essa história, isso tudo. Mas hoje eu já aceito, porque eu sei que é uma batalha, porque eu sei que ela queria isso, e eu não quero decepcionar ela.

Um guerreiro nunca foge da luta, nem que caia, mas ele levanta na frente, então se ela aceitou eu como uma guerreira, como filha dela, eu quero levar adiante, só mesmo o grande rio pra me tirar dessa história. 


\section{Nanduty}

ISSN:2317-8590

\section{O COMEÇO DE UM FIM}

A minha mãe Poty citou: um dia levaram tudo de mim, levaram o ouro, a prata, os rios, as matas, menos o meu jeito de ser índia, estou apenas catando as pedrinhas do meu caminho. Eu, Cacique Kawany Lourdes Tupinambá já falo: estou apenas continuando, resgatando os indígenas perdidos no caminho.

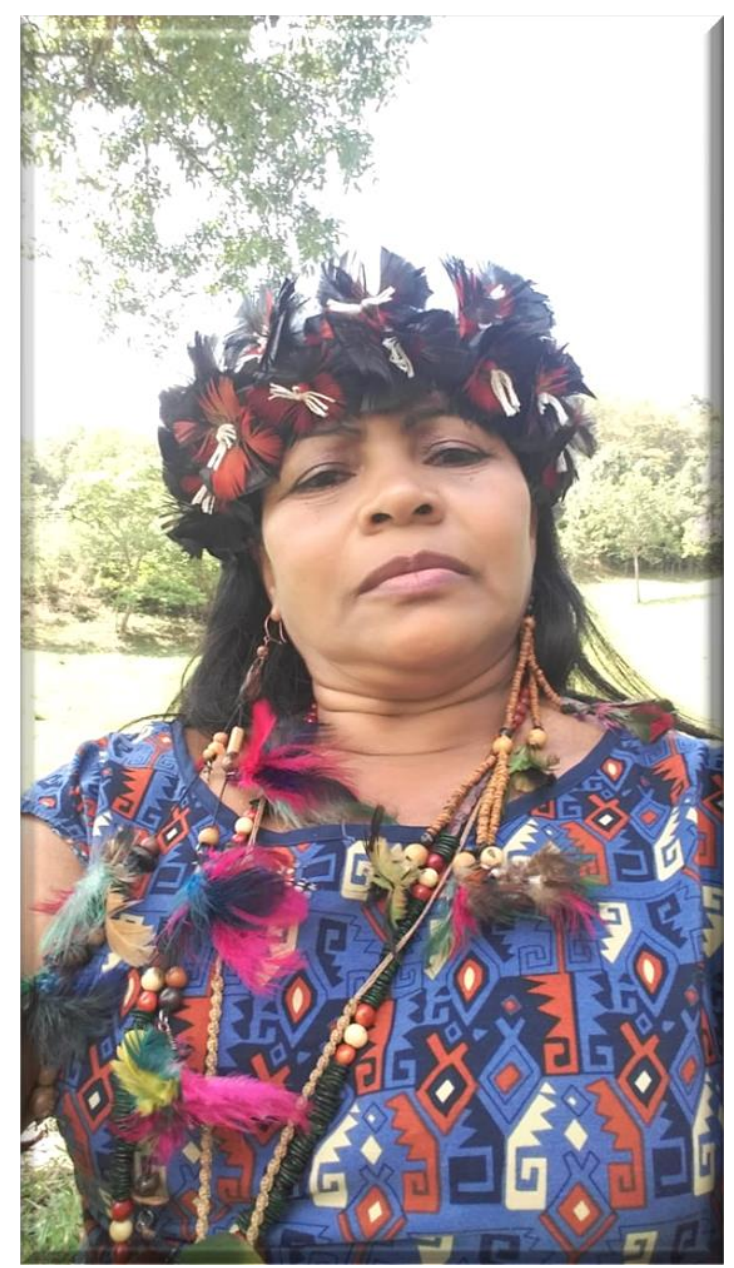

Imagem 1: Cacique Kawany Lourdes Tupinambá 


\section{REFERÊNCIAS BIBLIOGRÁFICAS}

ADICHIE, Chimamanda. 2010. O Perigo da História Única. Palestra conferida no Tecnology, Entertainment and Design (TED).

AMANTINO, Márcia. 2001. O mundo das feras: Os moradores do Sertão Oeste de Minas Gerais - século XVIII. 2001. 426 f. Tese (Doutorado em História) - Instituto de Filosofia e Ciências Humanas, Universidade Federal do Rio de Janeiro, Rio de Janeiro.

ARRUTI, José Maurício Andion Paiva. 1997. A emergência dos 'remanescentes': notas para o diálogo entre indígenas e quilombolas. Mana [online], Rio de Janeiro, v.3, n.2, p. 7-38, Oct. 2001.Agenciamentos Políticos da "Mistura": Identificação Étnica e Segmentação Negro-Indígena entre os Pankararú e os Xocó. In. Estudos Afro-Asiáticos, Ano 23, nº 2, p. 215-254

2006. Etnogêneses indígenas. In: BETO; FANY. Povos Indígenas no Brasil: 20012005. São Paulo: Instituto Socioambiental.

. 2006. Mocambo: Antropologia e História no processo de formação quilombola. São Paulo: EDUSC.

BENJAMIN, W. 1985. As Teses sobre o Conceito de História. In: Obras Escolhidas, Vol. 1, p. 222-232. São Paulo, Brasiliense.

BUTLER, Judith. 2003. Problemas de gênero: feminismo e subversão da identidade. Tradução Renato Aguiar. Rio de janeiro: Civilização Brasileira.

CARDOSO DE OLIVEIRA, Roberto. Aculturação e "friç̧ão interétnica". América Latina, v. 6, n. 3, p. 33-46, 1963.

CORRÊA, Carlos Humberto P. 1996. História Oral: considerações sobre suas raízes e objetivos. In. (Re)introduzindo história oral no Brasil. São Paulo: Xamã.

CUNHA, Manuela Carneiro da. 2014. Etnicidade: da cultura residual mas irredutível. In: Cultura com aspas e outros ensaios. São Paulo: Cosaic \& Naif, (p. 235 - 244).

FANON, Frantz. (1952) 2008. Pele Negra, Máscaras Brancas. Salvador: EDUFBA.

FILHO, Aurelino José Ferreira; PEDROSO, Leonardo Batista. 2010. Famílias Indígenas Não Aldeadas Urbanas no Triângulo Mineiro e Alto Paranaíba. Em extensão, Uberlândia, v.9, n.2, p. 36-41, jul./dez.

FREITAS, Sônia Maria. 2002. História Oral: Procedimentos e possibilidades. São Paulo: Humanitas USP.

GALVÃO, Eduardo. (1957) 1979. Estudos sobre aculturação dos povos indígenas no Brasil. Revista de Antropologia. v.5, n. 1. (8p) (on-line).

GODOI, Emilia Pietrafesa. 1999. O trabalho da memória: cotidiano e trabalho no sertão do Piauí. Campinas: Unicamp.

INGOLD, Tim. 2012. Trazendo as coisas de volta à vida: emaranhados criativos num mundo de materiais. Horizonte antropológico, vol.18, n.37, pp.25-44.

LUTZ, Catherine. 1995. The gender of theory. Women Writing Culture. Ed. Ruth Behar and Deborah Gordon. Berkeley: University of California Press, 249-66.

MONTEIRO, John. 2001. Tupis, Tapuias e os Historiadores: estudos de história indígena e do indigenismo. Tese de Livre Docência. IFCH - Unicamp. 


\section{Nanduty}

OLIVEIRA FILHO, Joao Pacheco. 1998. Uma Etnologia dos 'Índios Misturados'? Situação colonial, territorialização e fluxos culturais, Mana, vol.4, n.1, pp. 47-77.

QUIJANO, Aníbal. 2005. Colonialidade do poder, eurocentrismo e América Latina. In: LANDER, Edgardo (org). A colonialidade do saber: eurocentrismo e ciências sociais. Perspectivas latinoamericanas. Buenos Aires, Colección Sur Sur, pp.118-142.

RIBEIRO, Darcy. 1970. Os Índios e a Civilização. São Paulo: Círculo do Livro, s.d., $1^{\text {a }}$ ed. Rio de Janeiro: Civilização Brasileira.

SEGATO, Rita Laura. 2012. Gênero e colonialidade: em busca de chaves de leitura e de um vocabulário estratégico descolonial. Epistemologias feministas: ao encontro da crítica radical.

SENA, Custódia Selma. 2011 Uma narrativa mítica do sertão. In: Sena, C. S.; Suárez, M. Sentidos do Sertão. Goiânia: Cânone Editorial.

SILVA, Vagner Gonçalves et. al. 1994. Antropologia e Seus Espelhos - A etnografia vista pelos observados. São Paulo: USP.

SPIVAK, Gaiatry. 2010. Pode o subalterno falar? Belo Horizonte: Editora da UFMG.

STRATHERN, Marilyn. 2014. Fora de Contexto: as ficções persuasivas da Antropologia. In: O efeito etnográfico e outros ensaios. São Paulo: Cosac Naify. 